Cumhuriyet Üniversitesi Fen Fakültesi

Fen Bilimleri Dergisi (CFD), Cilt 38, No. 2 (2017) ISSN: $1300-1949$
Cumhuriyet University Faculty of Science

Science Journal (CSJ), Vol. 38, No. 2 (2017) ISSN: $1300-1949$

http://dx.doi.org/10.17776/cumuscij.304902

\title{
Artificial Neural Networks Can be Used as Alternative Method to Estimate Loss Tooth Root Sizes for Prediction of Dental Implants
}

\author{
Oğuzhan GÖRLER ${ }^{1 *}$, Serkan AKKOYUN ${ }^{2}$ \\ ${ }^{I}$ Department of Clinical Dentistry, Cumhuriyet University Faculty of Dentistry \\ ${ }^{2}$ Department of Physics, Cumhuriyet University Faculty of Science, Sivas, Turkey
}

Received: 08.04.2017; Accepted: 25.04.2017

\begin{abstract}
The aim of this study was to investigate the feasibility of estimation of canine root length and cervical width by an artificial neural network method with an appropriate setting. We randomly obtained 120 representative samples of routine panoramic radiographs by computer tomography (CT). Of 120 samples, 96 $(80 \%)$ were used in training phase and $24(20 \%)$ were used in test phase after a randomized selection. The intertuberal length (IL) of maxilla and canine root length (RL) and canine root cervical width (CW) of the right canine tooth was measured and was entered to a datum file. According to the results, the method is convenient with this purpose. The mean square error values are lied between $2 \%$ and $4.4 \%$ for the estimations. This shows that the ANN method is an alternative method for the canine root length and cervical width. The ANN software and system, which is a cost-effective tool to purchase, can be adapted to dental implant surgery after further study and optimization of software settings, allowing for the prediction of the size and width of implants in implant surgery.
\end{abstract}

Keywords: Neural Network, Dental Implant, Canine, Dentistry

\section{Dental İmplantlara Alternatif Değerlendirme Metodu Olarak Kayıp Dişlerin Boyutlarının Yapay Sinir Ağı Yöntemiyle Tahmini}

\begin{abstract}
Özet. Bu çalışmanın amacı, kanin diş kökü uzunluğu ve servikal genişliğinin yapay bir sinir ağı yöntemi (ANN) ile tahmin edilmesinin fizibilitesini araştırmaktır. Bilgisayarlı tomografilerin (BT) panoramic görüntüleri ile rasgele 120 hasta değerlendirildi. 120 örnekten 96'sı (\% 80) eğitim fazında, 24'ü (\% 20) randomize bir seçimden sonra test aşamasında kullanıldı. Sağ maksiller kanin kök uzunluğu (RL), servikal genişliği (CW) ve intertuberal uzunluk (IL) ölçülerek bir veri dosyasına oluşturuldu. Sonuçlara göre, yöntem bu amaca uygun bulundu. Tahminler için ortalama karesel hata değerleri \%2 ile \%4.4 arasında bulundu. Bu ANN yönteminin kanin kök boyu ve servikal genişliği için alternatif bir yöntem olduğunu göstermektedir. Satın alınabilecek uygun maliyetli bir araç olan ANN yazılımı ve sistemi, daha ileri çalışmalar ve yazılım ayarlarının optimizasyonundan sonra dental implant ameliyatına adapte edilebilir, implant ameliyatlarında implantların boy ve genişlikleri için öngörü imkanı verebilir.
\end{abstract}

Anahtar Kelimeler: Yapay Sinir Ağı Yöntemi, Dental İmplant, Kanin, Diş Hekimliği

\section{INTRODUCTION}

Implant rehabilitation of missing teeth has considerably widened the treatment options for both patients and clinicians after recent advances in implant design, materials, and techniques. Preference of implants has increased dramatically in the past two decades and a continuing increase is expected in the future. Success of dental implants depends on how it restores the function of the teeth just like

\footnotetext{
* Corresponding author. Email address: drgrlr@ymail.com
} 
original one such as chewing, biting, aesthetics and other oral functions [1]. Rehabilitation of severely resorbed jaws with dental implants remains a surgical and prosthetic challenge for clinicians [2].

Implant osseointegration is the result of a dynamic interactive process of bone formation and bone resorption, developed concomitantly. Taking into account the expected increase in the aged populations, osseointegration around implants might be adversely affected in accordance the compromised bone reparing mechanisms in this age group. This factor increases the importance of correct choose of appropriate size of implant [3]. The failure of dental implants is due not only to biological factors, such as unsuccessful osseointegration or the presence of periimplantitis, but they also result from technical complications that involve implant body/fixture fracture, abutment screw fracture, abutment fracture, fractured prosthesis, etc.

Dental implants are useful tools and represent a widely spread technique for oral rehabilitation. Their long standingness is highly influenced by the mechanical and geometrical properties of the surrounding osseous tissue in which they are placed. In some unsuccessful cases though, the dental implant is exposed to masticatory forces and other functional acts, and osseous tissue may resorb near its vicinity, leading to the dental implants loss.

Despite the high success rates in the vast number of pertinent literature, early or late implant failures are still encountered in prosthodontics [4] These events make the correct choose of appropriate size and design of the implant extremely crucial to improve the outcome implant placement. The outcome of implant treatment is often maximized when implants are placed in dense bone with an appropriate size of implant [5].

The method of artificial neural network (ANN) has been used in many fields including dentistry. [6,7] Several examples can be given as diagnosing artificial dental caries using images from a charged coupled device [8], supporting the clinical decision making on the maxillary implant restoration for the patient with edentulous maxilla [9], improving the radiographic diagnosis of proximal caries [10], classifying patients into aggressive periodontitis or chronic periodontitis patients class [11] and prediction of tooth surface loss in individuals without the need to conduct clinical examinations [12]. ANN is a mathematical model that mimics the human brain function. It consists of neurons, which are processing units. The neurons are connected to each other by weights. An advantage of the method is no relationship is needed between the input and output data belonging to the problem. Method produces outputs according to the given input variables. After the training of the ANN with known data and construction of the network properly, one can confidently predict outputs on unknown data. In this present study, five different variables from 120 volunteers have been used as inputs of the ANN. The aim of this study is to develop an ANN in order to obtain tooth root size according to the given inputs. After several trying, it was seen that the ANN method is convenient for this task within reasonably error levels.

In prosthodontics, deciding on the appropriate size of implants, dental surgeons need to depend on clinical experiences and the literature is still not conclusive concerning the choice of best size of implant. For the selection of proper size of implant, the most reliable parameters are the estimated width and length of lost tooth root. This reduces the chance of choosing inappropriately larger or smaller implants and improves the outcome of implant application.

\section{MATERIAL and METHODS}

\section{Materials}


In this study we used the dental database of our outpatient service of our faculty. We randomly obtained 120 representative samples of routine panoramic radiographs by Orthopantomograph OP300 Maxio's CT software (Figure 1). Of 120 samples, 96 (80\%) were used in training phase and $24(20 \%)$ were used in test phase after a randomized selection. Inclusion criteria were the following: panoramic radiographs of patients with a age range of 20-30 years and with normal canine teeth, no dental patient records related to any bone disorder that could affect the jaw bones. After collection of study panoramic radiographs, we measured intertuberal length (IL) of maxilla and canine root length (RL) and canine root cervical width $(\mathrm{CW})$ of the right canine tooth, and in addition, the canine length (CL) as whole canine tooth length, and entered their values to an datum file.

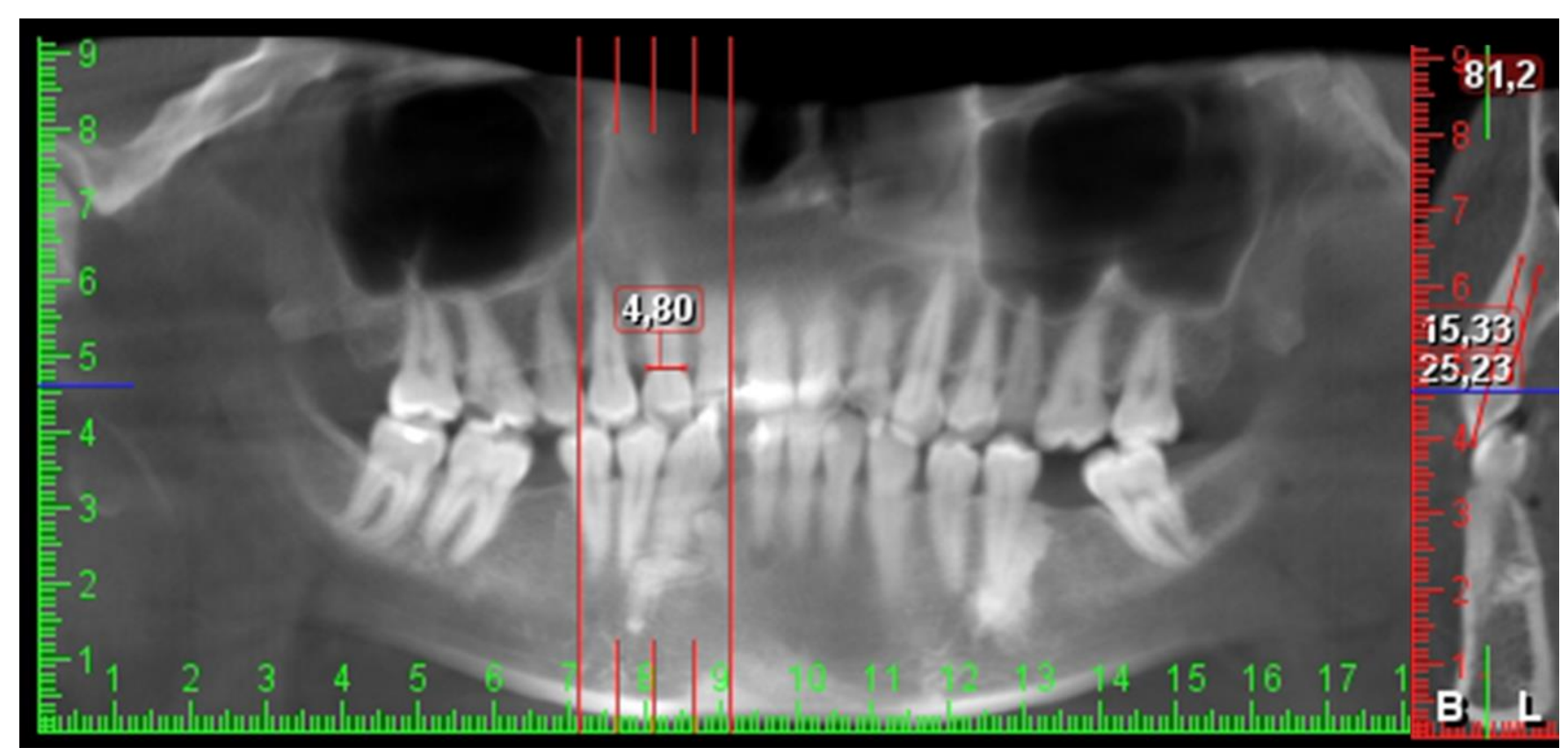

Figure 1. Measurements of intertuberal length $(108.0 \mathrm{~mm})$ of maxilla and canine root length $(15.33 \mathrm{~mm})$ and canine root cervical width $(4.8 \mathrm{~mm})$ of the right canine tooth in a representative Computer Tomography Panoramic radiograph.

\section{Method}

Artificial neural network (ANN) is a mathematical model [13]. It mimics human brain functionality. In this study, layered feed forward ANN as a universal function approximate [14] is used for estimating tooth root size. ANN has mainly three layers named as input, hidden and output layers. In these layers there are neurons, which are main processing units. Each neuron is connected to the other neurons in the next layer by adaptive synaptic weights. The task of the ANN is determining weights values for solving the problem. In other words, the task of the ANN is to give outputs as close as to the desired output values. The neurons in the input layer receive the data from environment and transmit via weights to the hidden layer. After activating and summing the values in each neuron, they are transmitted to the outputs. In this study, the neurons in the hidden and output layer have tangent hyperbolic (Eq. (1)) and linear activation function, respectively.

$$
\tanh x=\frac{e^{x}-e^{-x}}{e^{x}+e^{-x}}
$$


In order to estimate the RL and CW, we used 120 sample dental data including age and gender of patients and the IL, CL, RL and CW values. We have totally 4 input values as age, gender, IL and CL. Therefore, one input layer with four neurons, one hidden layer with four neurons $(h=4)$ and one output layer with two neurons (4-4-2) ANN architecture has been used for accurately estimation of RL and CW values (Figure 2).

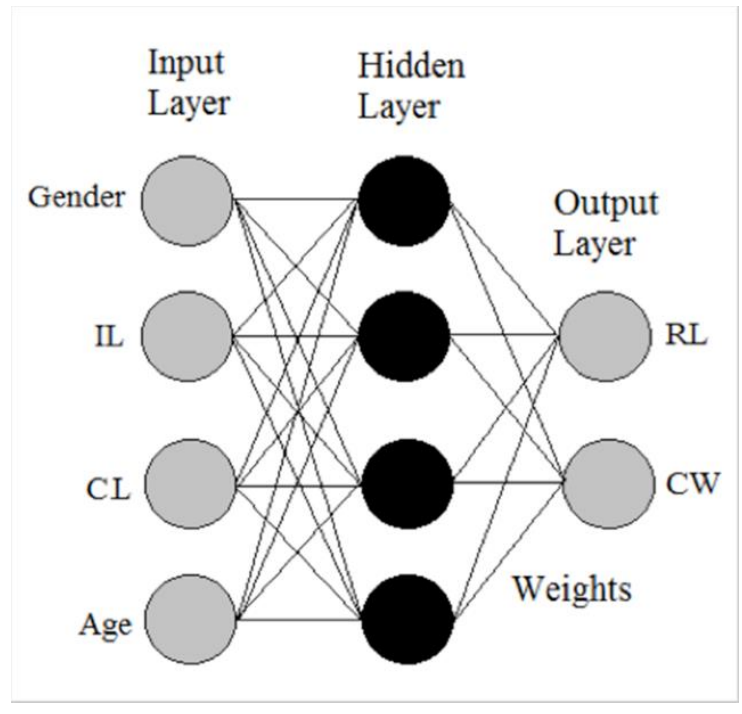

Figure 2. The 4-4-2 ANN topology for estimation of the canine root length $(18.3 \mathrm{~mm})$ and canine root cervical width $(4.5 \mathrm{~mm})$ of the right canine tooth

The total numbers of adjustable weights $(w)$ without bias were 24 according to Eq. 2 given by

$$
w=p \times h+r \times h
$$

Where $\mathrm{p}, \mathrm{h}$ and $\mathrm{r}$ are the neuron numbers in input, hidden and output layers. There is no a rule for determining the number of hidden layers and neurons. But generally single hidden layer is enough. The number of neurons in this layer depends on the problem nature. In this study, after several trials, hidden neuron number has been finally accepted as 4 giving the best results for the problem. An ANN software NeuroSolutions v6.02 [15] was used for the calculations. All data were divided into two parts. One part is for the training stage ( $80 \%$ of all data) and the rest is for the test stage (20\% of all data). For the training stage, a back-propagation algorithm with Levenberg-Marquardt [16,17] was used. By appropriate modifications, ANN modifies its all weights until an acceptable error level between estimated and desired (measured) outputs. The difference between these outputs was calculated by mean square error (MSE) given by:

$$
M S E=\frac{\sum_{i=1}^{N}(d-e)^{2}}{N}(3
$$

Where $\mathrm{N}$ is the number of training or test data, $\mathrm{d}$ and e are the desired and ANN estimated outputs, respectively. After obtaining the final weights by training of the ANN, the performance of the ANN has been tested on the training data. After seeing the success of the method, the constructed ANN has been tested on the test data, which has not been seen before by the ANN and has not been used in the 
training stage. If the estimations of the test data are sufficiently good, it has been confidently declared that ANN generalized the data.

\section{RESULTS}

We have used all 4 input parameters in the beginning of the work. These inputs are IL, CL, gender and age informations of the volunteers. In order to construct ANN for this problem, we have used only training data set for this purpose. After training of the ANN, we have tested constructed structure on the training data. Since it is used in this stage, this data is known by the ANN. We have estimated the tooth root size belonging to 96 volunteers data in training group. The measured and ANN estimated sizes (RL and CW) have been shown in Figure 3. As can be clearly seen in the figure that, the two results are close to each other. The MSE values are $0.64 \mathrm{~mm}$ for RL and $0.49 \mathrm{~mm}$ for $\mathrm{CW}$. If we take average RL and CW values as $17.6 \mathrm{~mm}$ and $6.65 \mathrm{~mm}$, respectively, the error values are in the order of $3.6 \%$ and $7.4 \%$.

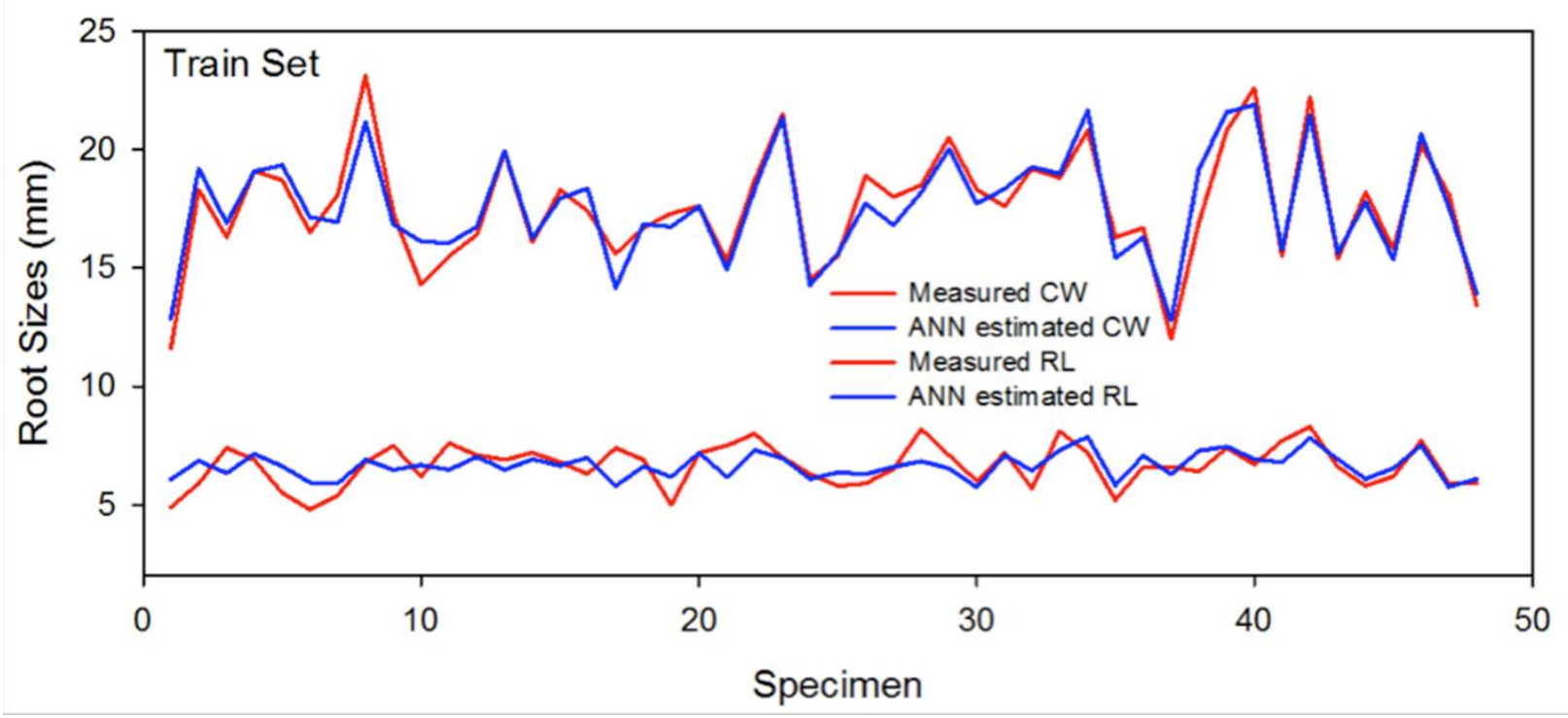

Figure 3. Measured and estimated RL and $\mathrm{CW}$ of in train stage.

In order to generalize the constructed ANN, it must be tested on the test data of 24 volunteers. This data has not been seen in the training stage. So, it is new for the ANN. The difference between measured and ANN estimated sizes have been shown in Figure 4. It is clear in the figure that, the ANN estimated results are very close to measured tooth root sizes (RL and CW). The maximum difference is about 1 and $1.5 \mathrm{~mm}$ for RL and CW, respectively. The MSE values are $0.34 \mathrm{~mm}$ and 0.29 $\mathrm{mm}$ for RL and CW, respectively. If we take average RL and CW values as $17.3 \mathrm{~mm}$ and $6.57 \mathrm{~mm}$, the error values are in the order of $2.0 \%$ and $4.4 \%$, respectively. The maximum and minimum absolutely errors are 0.0 and $2.0 \mathrm{~mm}$ for train data. For the test data, these values are between 0.1 and $1.0 \mathrm{~mm}$ for RL, 0.0 and 1.3 for $\mathrm{CW}$. 


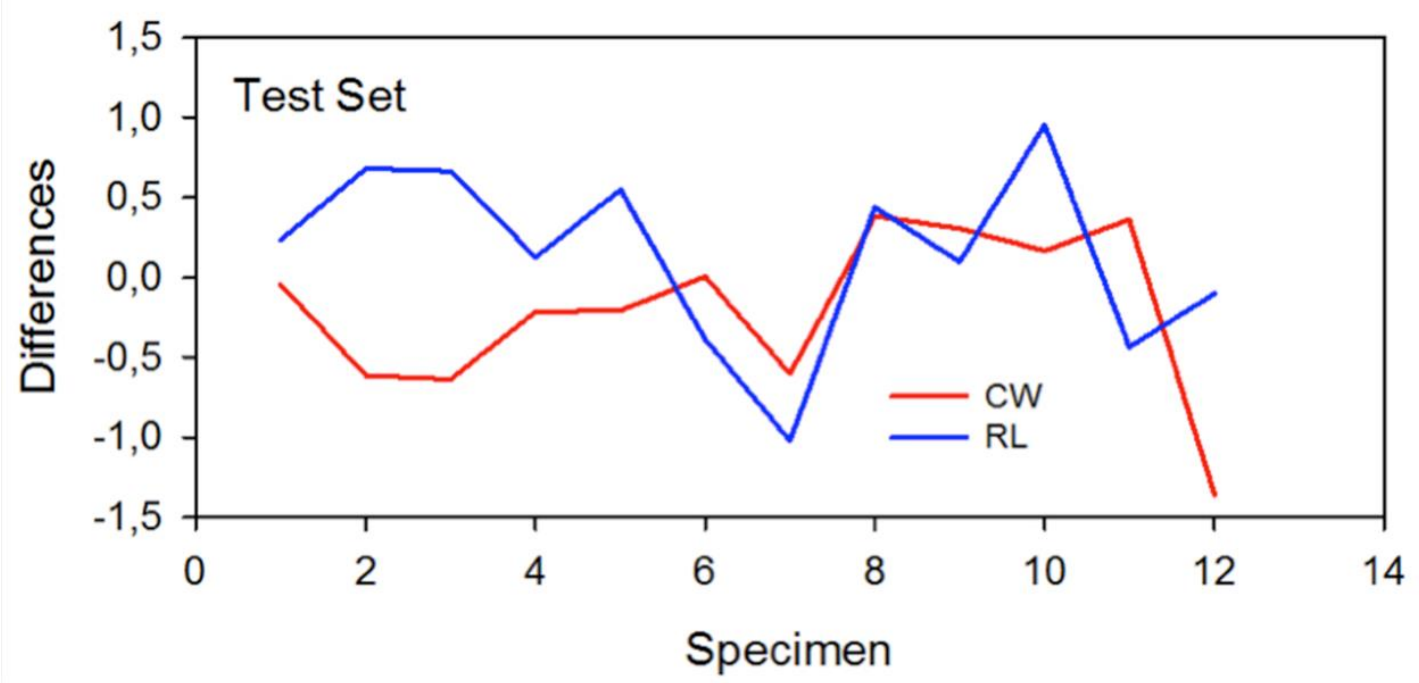

Figure 4. Difference between measured and estimated RL and CW for specimens aged between 20 and 28 in test stage.

Table 1. The inputs and output of the ANN for the estimation of canine root length (RL) (mm) and cervical width $(\mathrm{CW})(\mathrm{mm})$ in a sample data set $(\mathrm{n}=12)$.

\begin{tabular}{|l|l|l|l|l|l|l|l|l|l|}
\hline Gender & Age & $\begin{array}{l}\text { Intertuberal } \\
\text { length }\end{array}$ & $\begin{array}{l}\text { Canine } \\
\text { length }\end{array}$ & $\begin{array}{l}\text { RL } \\
\text { (measured) }\end{array}$ & $\begin{array}{l}\text { RL } \\
\text { (estimated.) }\end{array}$ & $\begin{array}{l}\text { RL } \\
\text { (difference) }\end{array}$ & $\begin{array}{l}\text { CW } \\
\text { (measured) }\end{array}$ & $\begin{array}{l}\text { CW } \\
\text { (estimated) }\end{array}$ & \begin{tabular}{l} 
(difference) \\
\hline Woman
\end{tabular} \\
\hline Woman & 25 & 130.4 & 21.9 & 14.1 & 13.9 & 0.2 & 6.9 & 7.0 & -0.1 \\
\hline Man & 22 & 118.2 & 27.6 & 19.4 & 18,7 & 0.7 & 5.8 & 6.4 & -0.6 \\
\hline Man & 23 & 118.7 & 25.9 & 16.1 & 16.5 & -0.4 & 7.2 & 6.8 & 0.4 \\
\hline Woman & 25 & 134.4 & 26.2 & 17.7 & 17.6 & 0.1 & 7.1 & 7.3 & -0.2 \\
\hline Woman & 21 & 107.7 & 25.5 & 17.8 & 17.3 & 0.5 & 5.9 & 6.1 & -0.2 \\
\hline Man & 20 & 131.9 & 32.3 & 21.7 & 21.3 & 0.4 & 7.6 & 7.2 & 0.4 \\
\hline Man & 20 & 141.0 & 27.9 & 18.0 & 17.9 & 0.1 & 7.5 & 7.2 & 0.3 \\
\hline Man & 25 & 140.5 & 27.5 & 19.0 & 18.0 & 1.0 & 7.4 & 7.2 & 0.2 \\
\hline Woman & 20 & 126.2 & 24.2 & 15.2 & 15.6 & -0.4 & 7.0 & 7.0 & 0.0 \\
\hline Woman & 24 & 107.5 & 26.6 & 17.6 & 18.6 & -1.0 & 5.9 & 6.5 & -0.6 \\
\hline Woman & 22 & 105.0 & 20.7 & 13.3 & 13.4 & -0.1 & 4.5 & 5.8 & -1.3 \\
\hline
\end{tabular}




\section{DISCUSSION}

In this study, we used an ANN software to estimate the implant length and width of patients. We choose canine tooth as a representative of all the teeth and with an appropriate setting of the software, we obtained trained weights of neurons. Later we tested these weight settings for the estimation of canine root length and width of a group of patients. We found that after training procedure with an adequate and well-selected data, this setup can be used successfully for the estimation of canine root length and width of patients. We think that after a training procedure for all teeth, an ANN software can be used in a clinical study. After an appropriate setting, commercial ANN software can be used to predict implant length and width after entering the age, gender, IL, and CL parameters.

We have used different group of input variables for the ANN in order to see the effect of the individual input parameters on the results. In one of these, we have used gender, CL and age as inputs of the ANN by excluding IL. The MSE values for training and test data sets are 0.74 and $0.35 \mathrm{~mm}$ for the RL and 0.62 and $0.61 \mathrm{~mm}$ for the $\mathrm{CW}$, respectively. This result shows that the IL is important for determining the root sizes. Due to the fact that it is width information of the chin, it is affect the CW results with larger impact than RL. We have taken another input group of the ANN by considering IL and excluding CL. We have used gender, IL and age as inputs. According to the result, we have estimated the root sizes with MSE values as 3.9 and 4.9 for RL in training and test data sets, respectively. For the test data these values are 0.52 and 0.46 for $\mathrm{CW}$ in training and test data set, respectively. Very large increase in MSE values of RL indicates that the CL is highly correlated with the RL value. Therefore, CL must be in among the input parameters. Hence, we have confidently suggest that the CL is very important in determining the root sizes especially in RL. In another trying we have considered IL, CL and age as inputs of the ANN by excluding gender information. We have obtained MSE values for training and test data as 0.75 and 0.47 for RL and 0.53 and 0.36 for CW, respectively. These error levels are not so bad compared to complete input set error values. We can conclude that the gender information would be better for estimating the root sizes. Similarly, we have taken inputs of ANN as gender, IL and CL. In this last trying we have excluded age information. The obtained MSE values show that the age information is also important for determining root size. The error values are 0.72 and 0.49 for RL and 0.52 and 0.38 for $\mathrm{CW}$ in training and test data sets, respectively.

Dental implant techniques are one of the important research topic in the past few years and is expected to expand in the future due to the recent growth of the global market for dental implants and the rising in the demand for cosmetic dentistry [18]. During planning of implant treatment, several clinical factors need to be considered, including chose of implant with appropriate size. In a recent review of Cochrane, the authors reviewed the clinical outcomes of dental implants those have different materials, shapes, and different surface characteristics. Considering clinical studies with reliably findings, they concluded that there was no clinical evidence showing that any implant with particular characteristics provides a good outcome with a long-term success. Taking into account current clinical knowledge, we need to give importance to the selection of implant with proper width and length in addition to searching for the best available implant type [19].

Two-dimensional radiographs provide satisfactory data during decision-making for appropriate determination of implant size [20,30]. Panoramic images provide an overview of the jaws and are usually considered adequate in the initial evaluation of the implant site [23], although they not provide diagnostic information in some areas of jaws such as the bucco-lingual aspect of the alveolar bone [21]. Knowledge of anatomic features like the location of the mandibular canal, the maxillary sinuses and the nasal cavity, as well as of the angulation and bone volume of the alveolar crest is a prerequisite 
for appropriate implant treatment planning [21, 23, 31]. Compared with cone-beam computed tomography (CBCT), PR has some advantages such as lower dose, fast operation, low cost, and larger popularity [24]. In recent years, the CBCT has increasingly used to choose appropriate size implant for a successful treatment planning, although there is no consensus about it indication because of important considerations such as the added cost, potential inconvenience of obtaining a scan, and amount of radiation exposure in every imaging [20, 26-29].

Many authors concluded that CBCT with current specifications need to be used a screening tool if routine panoramic radiographs did not provide the required information for the dental surgeon [20, 3234]. Among the important indications of CBCT, there are needs for better exposure of surgical site for quidded surgery, reducing the risk of vital structures, planning for bone grafting [20, 35, 36]. Dau et al. [25] compared the preference of panoramic radiography and CBCT in planning of dental implant procedures by clinicians with different educational background. They noted that the majority of participants rated an additional CBCT as required (14.0\%) or reasonable (56.1\%). The authors concluded that especially in the anterior and posterior maxillary regions, the participants preferred an additional CBCT for planning of dental implant procedures.

In a recent study [20], the implant size and need for bone grafting were determined cone-beam computed tomography (CBCT) in addition the panoramic radiograph and clinical examination. After assessing the contribution of CBCT to their management, the authors found that two methods accurately predict implant width and length to within $1.5 \mathrm{~mm}$ of the implant actually placed in $100 \%$ and $95 \%$ of cases, respectively. The authors concluded that in accordance with technological improvements reducing radiation dose, $\mathrm{CBCT}$ has a merit for an established place in implantology [20,36]. Correa et al [21]. Conducted a study to assess the clinical value of dental implant size determined with digital and CBCT-generated panoramic images and CBCT cross-sectional images. The concluded that the selected implant size can differs when planned on panoramic or cross-section CBCT images, and that In most cases, implant size measured in cross-section images was narrower and shorter than implant size measured in a panoramic image or CBCT-based panoramic view.

After a review of current literature on the imaging modalities for the planning of implant size, it can be seen that there is considerably variation in preference of digital panoramic radiographs and CBCTbased images regarding indications and in the acceptance of their usage regarding information obtained by their evaluation. We think that although with the pace of current work on the development ad improvement of these imaging modalities, in the future, there will be considerable increase their accuracy to help dental surgeons for the placement of appropriate implants in especially difficult cases with jawbone problems. To obtain best outcome after dental implant placement, we need to consider other factor in addition to the criterion as the adequacy of bone in the implantation site. Our clinical experience suggests that there may be other factors playing some roles in the complex relationship of bone with dental implant. We need to consider that the lost tooth has a root that is formed by several effects related to chewing forces and nearby bone tissue. The findings of our study support that with well-trained ANN software; the size of an implant can be determined with the help of several jawbones and tooth size parameters. We think that the better we predict the implant size for the loss tooth according to the anatomic structure, the more success we can achieve in implant surgery

An ANN software can be easily adapted according to the need so the implant surgery after proper setting and training procedures that can be easily performed by an experienced person and it can have a place in implant surgery after further expanded studies and optimization of software setting. According to the ANN results, the RL values are better predicted with less error than CW values. 
Thus, we can conclude that the RL value is in a stronger relationship with the input parameters than $\mathrm{CW}$ value. This may be related to the inclusion of length related data as input in ANN system.

\section{REFERENCES}

[1]. B K Biwa's, S Bag, S Pal, Biomechanıcal Analysıs Of Normal And Implanted Tooth Using Bitıng Force Measurement. International Journal of Engineering and Applied Sciences, August 2013. Vol. 4, No. 2.

[2]. Nisand D, Renouard F. Short implant in limited bone volume. Periodontal 2000. 2014 Oct;66(1):72-96.

[3]. Wen B, Chen J, Dard M, Cai Z. The Performance of Titanium-Zirconium Implants in the Elderly: A Biomechanical Comparative Study in the Minipig. Clin Implant Dent Relat Res. 2016 Dec;18(6):1200-1209.

[4]. Esposito M, Hirsch J-M, Lekholm U, Thomsen P. Biological factors contributing to failures of osseointegrated oral implants (II) Etiopathogenesis. European Journal of Oral Sciences 1998;106: $721-64$.

[5]. Sahin S, Cehreli MC, Yalçin E. The influence of functional forces on the biomechanics of implant-supported prostheses--a review. J Dent. 2002 Sep-Nov;30(7-8):271-82.

[6]. Filippo Amato, Alberto López, Eladia María Peña-Méndez, Petr Vaňhara, Aleš Hamp, Josef Havel, Artificial neural networks in medical diagnosis. J Appl Biomed. 11: 47-58, 2013.

[7]. Stefan Raitha, Eric Per Vogela, Naeema Aneesa, Christine Keulb, Jan-Frederik Güthb, Daniel Edelhoffb, Horst Fischera, Artificial Neural Networks as a powerful numerical tool to classify specific features of a tooth based on 3D scan data. Computers in Biology and Medicine 80 (2017) 65-76.

[8]. Suwadee Kositbowornchai, Sanphet Siriteptawee, Supattra Plermkamon, Sujin Bureerat, Danaipong Chetchotsak, An artificial neural network for detection of simulated dental caries, Int J CARS (2006) 1:91-96.

[9]. Leyla Sadighpour, Susan Mir Mohammad Rezaei, Mojgan Paknejad, Fatemeh Jafaryand Pooya Aslani, The Application of an Artificial Neural Network to Support Decision Making in Edentulous Maxillary Implant Prostheses, Journal of Research and Practice in Dentistry, Vol. 2014 (2014), Article ID 369025, 10 pages.

[10]. Karina Lopes Devito, Flávio de Souza Barbosa, and Waldir Neme Felippe Filho, An artificial multilayer perceptron neural network for diagnosis of proximal dental caries, Oral Surg Oral Med Oral Pathol Oral Radiol Endod 2008;106:879-884

[11]. Georgios Papantonopoulos, Keiso Takahashi, Tasos Bountis, Bruno G. Loos, Artificial Neural Networks for the Diagnosis of Aggressive Periodontitis Trained by Immunologic Parameters, PLoS ONE 9(3), 2014, e89757.

[12]. Ali Al Haidan, Osama Abu-Hammad, and Najla Dar-Odeh, Predicting Tooth Surface Loss Using Genetic Algorithms-Optimized Artificial Neural Networks, Computational and Mathematical Methods in Medicine Volume 2014, Article ID 106236, 7 pages.

[13]. Haykin S. Neural networks: a comprehensive foundation. 2nd ed. New Jersey: Prentice-Hall; 1999.

[14]. Hornik K, Stinchcombe M, White H. Multilayer feedforward networks are universal approximator. Neural Networks 1989;2:359-66.

[15]. Neurosolutions, http://www.neurosolutions.com/.

[16]. Levenberg KA. Method for the solution of certain non-linear problems in least squares. Q Appl Math 1944;2:164-8. 
[17]. Marquardt D. An algorithm for least-squares estimation of nonlinear parameters. SIAM J Appl Math 1963;11:431-41.

[18]. Laura Gaviria, John Paul Salcido, Teja Guda, and Joo L. Ong. Current trends in dental implants. J Korean Assoc Oral Maxillofac Surg. 2014 Apr; 40(2): 50-60.

[19]. Esposito M, Ardebili Y, Worthington HV.Interventions for replacing missing teeth: different types of dental implants. Cochrane Database Syst Rev. 2014 Jul 22;(7):CD003815.

[20]. Deeb G, Antonos L, Tack S, Carrico C, Laskin D, Deeb JG. Is Cone Beam Computed Tomography Always Necessary for Dental Implant Placement? J Oral Maxillofac Surg. 2016 Nov 15. pii: S0278-2391(16)31172-7.

[21]. Correa LR, Spin-Neto R, Stavropoulos A, Schropp L, da Silveira HE, Wenzel A. Planning of dental implant size with digital panoramic radiographs, CBCT-generated panoramic images, and CBCT cross-sectional images. Clin Oral Implants Res. 2014 Jun;25(6):690-5.

[22]. Lofthag-Hansen S, Thilander-Klang A, Ekestubbe A, Helmrot E, Gröndahl K. Calculating effective dose on a cone beam computed tomography device: 3D Accuitomo and 3D Accuitomo FPD. Dentomaxillofac Radiol. 2008 Feb;37(2):72-9.

[23]. Mesquita Júnior EJ, Vieta AI, Taba Júnior M, Faria PE. Correlation of radiographic analysis during initial planning and tactile perception during the placement of implants. Br $\mathrm{J}$ Oral Maxillofac Surg. 2016 Sep 12. pii: S0266-4356(16)30233-9.

[24]. Cheng DC, Chen LW, Shen YW, Fuh LJ. Computer-assisted system on mandibular canal detection. Biomed Tech (Berl). 2016 Nov 18.

[25]. Dau M, Edalatpour A, Schulze R, Al-Nawas B, Alshihri A, Kämmerer PW. Presurgical evaluation of bony implant sites using panoramic radiography and cone beam computed tomography - influence of medical education. Dentomaxillofac Radiol. 2016 Oct 19:20160081.

[26]. Malina-Altzinger J, Damerau G, Grätz KW, Stadlinger PD. Evaluation of the maxillary sinus in panoramic radiography-a comparative study. Int J Implant Dent. 2015 Dec;1(1):17. Epub 2015 Jul 10.

[27]. Wolff C, Mücke T, Wagenpfeil S, Kanatas A, Bissinger O, Deppe H. Do CBCT scans alter surgical treatment plans? Comparison of preoperative surgical diagnosis using panoramic versus cone-beam CT images. J Craniomaxillofac Surg. 2016 Oct;44(10):1700-1705.

[28]. Jung YH, Cho BH. Assessment of maxillary third molars with panoramic radiography and conebeam computed tomography. Imaging Sci Dent. 2015 Dec;45(4):233-40.

[29]. Lopes LJ, Gamba TO, Bertinato JV, Freitas DQ. Comparison of panoramic radiography and CBCT to identify maxillary posterior roots invading the maxillary sinus. Dentomaxillofac Radiol. 2016;45(6):20160043.

[30]. Val JE, Gómez-Moreno G, Ruiz-Linares M, Frutos JC, Gehrke SA, Calvo-Guirado JL. Effects of Surface Treatment Modification and Implant Design in Implants Placed Crestal and Subcrestally Applying Delayed Loading Protocol. J Craniofac Surg. 2016 Dec 14.

[31]. Khojasteh A, Motamedian SR, Sharifzadeh N, Zadeh HH. The influence of initial alveolar ridge defect morphology on the outcome of implants in augmented atrophic posterior mandible: an exploratory retrospective study. Clin Oral Implants Res. 2016 Nov 2.

[32]. Bucchi C, Borie E, Arias A, Dias FJ, Fuentes R. Radiopacity of alloplastic bone grafts measured with cone beam computed tomography: An analysis in rabbit calvaria. Bosn J Basic Med Sci. 2016 Nov 22.

[33]. Chopra A, Mhapuskar AA, Marathe S, Nisa SU, Thopte S, Saddiwal R. Evaluation of Osseointegration in Implants using Digital Orthopantomogram and Cone Beam Computed Tomography. J Contemp Dent Pract. 2016 Nov 1;17(11):953-957. 
[34]. Varshowsaz M, Goorang S, Ehsani S, Azizi Z, Rahimian S. Comparison of Tissue Density in Hounsfield Units in Computed Tomography and Cone Beam Computed Tomography. J Dent (Tehran). 2016 Mar;13(2):108-115.

[35]. Tadinada A, Jalali E, Al-Salman W, Jambhekar S, Katechia B, Almas K. Prevalence of bony septa, antral pathology, and dimensions of the maxillary sinus from a sinus augmentation perspective: A retrospective cone-beam computed tomography study. Imaging Sci Dent. 2016 Jun;46(2):109-15.

[36]. Nart J, Barallat L, Jimenez D, Mestres J, Gómez A, Carrasco MA, Violant D, Ruíz-Magaz V. Radiographic and histological evaluation of deproteinized bovine bone mineral vs. deproteinized bovine bone mineral with $10 \%$ collagen in ridge preservation. A randomized controlled clinical trial. Clin Oral Implants Res. 2016 Jun 22.

[37]. Umanjec-Korac S, Parsa A, Darvishan Nikoozad A, Wismeijer D, Hassan B. Accuracy of cone beam computed tomography in following simulated autogenous graft resorption in maxillary sinus augmentation procedure: an ex vivo study. Dentomaxillofac Radiol. 2016 May 26:20160092. 